\title{
Laurence Pullar, LL.D.
}

IN the death of Laurence Pullar, we have to regret the loss of one of the most successful business men in the list of our Fellows, who, by his generosity, promoted scientific research in the land which he loved so well. Born in Perth in 1838, he passed away on 22nd December 1926, at the great age of 88 , beloved by a large circle outside the range of his own relatives. The fourth son of Lord Provost Pullar of Perth, and brother of Sir Robert Pullar, he was gifted in large measure with the business capacity and shrewdness which characterised that family.

Beginning life as an engineer, he was appointed at an early age manager of the Keirfield Manufacturing Works at Bridge of Allan, which, with his younger brother Edmund Pullar as partner, was subsequently acquired from his father. By his industry and enterprise these works were remarkably successful. It has been recorded that they achieved for Bridge of Allan what Pullar's Dye Works have done for Perth.

While most of his time and thought were naturally devoted to the development of his business, he showed, at the same time, his breadth of outlook on life by his public service and by his gifts to the people among whom he lived. For many years he served as a member of Bridge of Allan Town Council, and eventually became Chief Magistrate. $\mathrm{He}$ took an active interest in the Volunteer Movement, and, as an officer, he stimulated the young men around him to join the force and undergo training for the defence of their country. By nature kind hearted, generous, and unostentatious, he performed many acts of kindness which were highly appreciated by those around him. One instance may suffice. The necessity for an improved water supply for Bridge of Earn, where he lived for many years after leaving Bridge of Allan, gave him an opportunity. He purchased the then existing works, made a new and larger reservoir, increased the sources of supply, and presented the new works as a gift to the community.

Laurence Pullar's interest in scientific research was stimulated, if not aroused, by his life-long friendship with Sir John Murray. The light thrown upon the physical and biological conditions of the great ocean basins during the Challenger and subsequent deep-sea expeditions led Murray to examine the Scottish sea-lochs. With Pullar's financial aid a steam yacht was built and equipped for oceanographical work near the 
shore, which enabled Murray to carry on these investigations for several years. While this work was in progress he examined the fresh-water lochs in the line of the Caledonian Canal, and found a remarkable difference in their physical and biological conditions when compared with those of the sea-lochs. In view of this divergence, Murray inferred that a systematic survey of the Scottish fresh-water lochs would result in important additions to our knowledge bearing on these problems. On his initiative the Councils of the Royal Society, and of the Royal Society of Edinburgh, appealed to the Secretary of H.M. Treasury to undertake the bathymetrical survey of the Scottish freshwater lakes, but the appeal was unsuccessful.

In 1897 Murray began the survey of the fresh-water lochs in the Forth Basin with the co-operation of Laurence Pullar's only son, Frederick, a young scientist of great promise. Unfortunately, the operations were suddenly checked by the tragic death of the son, Frederick, in 1901, when attempting to rescue the lives of others in an ice accident. Murray thought, after this sad event, of abandoning the survey altogether, but Laurence Pullar wished that the work in which his son had taken such an active interest should be brought to a satisfactory conclusion.

He placed a sum of $£ 10,000$ under trust, on condition that Murray should supervise the operations and appoint an adequate scientific staff to complete the work. The Admiralty and Ordnance Survey Departments placed maps at their disposal, and the Board of Education, through Sir Jethro Teall, the Director of the Geological Survey, sanctioned the issue to the Lake Survey Staff of a complete set of the Geological Survey Maps of Scotland and the supply of geological information in the course of these investigations.

The work thus organised was resumed in 1902, and by the end of 1906 the survey of 562 lakes was completed. In 1907 biological observations were continued, and physical observations were carried on during the years 1908 and 1909. The results of these elaborate researches were published in 1910 in six handsome volumes, dedicated to the memory of the son, Frederick Pattison Pullar, who took an active part in the initiation of the systematic survey of the Scottish fresh-water lakes.

These volumes embody contributions to our knowledge of the highest value. To Murray belongs the credit of directing the operations, and to Laurence Pullar we are indebted for the financial aid which enabled the work to be done and published on an adequate scale. 
During the progress of this work the writer of this notice frequently came in contact with Laurence Pullar, who showed keen interest in some of the problems connected with the Scottish lakes, in particular, the controverted question of the origin of rock-basins. His willingness to encourage research was no less apparent. During the course of his career he was asked to contribute to the publication of papers relating to Scottish geology, communicated to this Society by authors who were not eligible for grants from the Carnegie Trust. No appeal was refused. When, near the close of his career, he was thanked in a personal interview for his financial help to this Society, his reply was typical of the man, "When the quality of the work is guaranteed, I am glad to help in a quiet way." In recognition of his generosity in the promotion of scientific research he received from the University of Edinburgh, on 20th July 1926, the Hon. Degree of LL.D.

A striking proof of his willingness to promote the development of natural science in his native land was the gift of $£ 20,000$ to Edinburgh University to aid in the erection of a new Department of Zoology. It is due to Laurence Pullar's memory to remember his gifts with gratitude. One may express the hope that others may follow his noble example.

He was elected a Fellow of this Society in 1903.

J. H. 